\title{
PENGARUH PERCEIVED ENTREPRENEURIAL FEASIBILITY DAN ATTITUDE TERHADAP NIAT KEWIRAUSAHAAN YANG BERORIENTASI BERKELANJUTAN
}

\author{
Andre Saputra dan Ida Puspitowati \\ Program Studi Manajemen Fakultas Ekonomi dan Bisnis, Universitas Tarumanagara, Jakarta \\ andresaputra545@gmail.com
}

\begin{abstract}
The purpose of this study was to test empirically the effect of perceived entrepreneurial feasibility and attitude towards entrepreneurial intentions with a sustainable orientation. The population of this study was students of the Universitas Tarumanagara, Faculty of Economics and Business. The number of sample used in this study was 170 respondents. The sampling technique used was non probability sampling with purposive sampling method. Overall the results and conclusions of this study are: 1) Perceived entrepreneurial feasibility has a positive and significant effect on entrepreneurial intentions that are oriented sustainably on students of the Tarumanagara University's Economics and Business Faculty. 2) Attitude has a positive and significant effect on entrepreneurial intentions that are oriented sustainably on the students of the Tarumanagara University's Economics and Business Faculty.
\end{abstract}

Abstrak: Tujuan penelitian ini adalah untuk menguji secara empiris mengenai pengaruh perceived entrepreneurial feasibility dan attitude terhadap niat kewirausahaan yang berorientasi berkelanjutan. Populasi dalam penelitian ini adalah Mahasiswa/I Fakultas Ekonomi dan Bisnis Universitas Tarumanagara. Sampel yang digunakan pada penelitian ini yaitu 170 reponden. Teknik pengambilan sampel yang digunakan yaitu non probability sampling dengan metode pengambilan sampel purposive sampling. Secara keseluruhan hasil dan kesimpulan dari penelitian ini yaitu: 1) Perceived entrepreneurial feasibility berpengaruh positif dan signifikan terhadap niat kewirausahaan yang berorientasi berkelanjutan pada Mahasiswa/I Fakultas Ekonomi dan Bisnis Univeristas Tarumanagara. 2) Attitude berpengaruh positif dan signifikan terhadap niat kewirausahaan yang berorientasi berkelanjutan pada Mahasiswa/I Fakultas Ekonomi dan Bisnis Univeristas Tarumanagara.

Keywords: perceived entrepreneurial feasibility, attitude, sustainable entrepreneurial intentions.

\section{LATAR BELAKANG}

Permasalahan yang dihadapi oleh Negara Sedang Berkembang pada umumnya seperti kemiskinan, distribusi pendapatan dan pengangguran. Badan Pusat Statistik (BPS) melaporkan jumlah pengangguran periode Agustus 2020 mengalami peningkatan sebanyak 2,67 juta orang. Adapun untuk penduduk miskin menurut Badan Pusat Statistik (2019) dilaporkan bahwa persentase penduduk miskin pada Maret 2019 sebesar 9,41 persen yang dimana besarnya pendapatan per rumah tangga miskin secara rata-rata adalah sebesar Rp1.990.170,-/rumah tangga miskin/bulan dan jumlah rumah tangga miskin terus bertambah pada saat COVID-19 masuk ke Indonesia.

Hal ini menjadi sebuah tantangan bagi Pemerintah untuk menyelesaikan permasalahan yang berkaitan dengan banyak aspek. Sebagai salah satu solusi untuk mengatasi pengangguran adalah dengan menerapkan nilai kewirausahaan dalam diri setiap orang, penerapan ini dapat 
dilakukan dengan berlandaskan teori yang ada dalam dunia pendidikan. Nilai-nilai yang terdapat dalam kewirausahaan dapat mendukung niat kewirausahaan terhadap setiap individu, yang terdiri dari Perceived Entrepreneurial Feasibility dan Attitude (Muselman dkk.,2009).

Perceived entrepreneurial feasibility (kelayakan kewirausahaan yang dirasakan) adalah tingkat keyakinan seseorang bahwa dirinya memiliki keterampilan dan pengetahuan yang diperlukan untuk menjadi wirausaha (Krueger, 1993; Shapero \& Sokol, 1982), Attitude (sikap) merupakan kecenderungan psikologis yang diungkapkan dengan mengevaluasi keadaan tertentu dengan beberapa tingkat disukai atau tidak disukai (Eagly \& Chaiken, 1992 dalam Sarlito, 2002).

Perceived entrepreneurial feasibility dan attitude, sudah banyak diterapkan dalam dunia kewirausahaan untuk membuat setiap orang sadar akan potensinya untuk memulai usaha, namun apabila dilihat dari hasil yang terlaksana di Indonesia masih sangat kurang. Menurut Menteri Koperasi dan UKM Puspayoga (2020), "jumlah pengusaha di Indonesia meningkat dari yang sebelumnya hanya sebesar $1,67 \%$ menjadi $3,10 \%$ dari total jumlah penduduk Indonesia yang saat ini sebanyak 225 juta jiwa”.

Sejalan dengan pemikiran pada Pembangunan Berkelanjutan, demikian halnya pada Kewirausahaan dapat diarahkan pada bentuk kewirausahaan yang berorientasi berkelanjutan . Selanjutnya berdasarkan hal tersebut penting untuk diketahui pendalaman mengenai penelitian nilai-nilai kewirausahaan yang terdiri Perceived entrepreneurial feasibility dan attitude, yang berdampak terhadap kewirausahaan serta menimbulkan niat kewirausahaan.

Seperti halnya pendapat dalam The Global Tomorrow Coalition (2013) dimana pembangunan ekonomi dan kesehatan lingkungan merupakan dua hal pokok yang saling berkaitan. Hal tersebut di perkuat oleh pendapat Hidayati (2013) bahwa perencanaan pembangunan infrastruktur di Indonesia selama ini sangat jarang mempertimbangkan aspek lingkungan. Sebagai salah satu bukti adalah kesalahan dalam pembuatan Analisis Mengenai Dampak Lingkungan (AMDAL) dalam pembangunan jalan di atas perairan (JDP) di Bali yang menghubungkan Denpasar (Bandara Ngurah Rai) dan Nusa Dua. Berdasarkan hal tersebut diketahui bahwa pembangunan yang tidak memikirkan dampak dari pembangunan, tentu memiliki dampak negatif terhadap lingkungan. Hal tersebut juga berada pada lingkungan bisnis."

Menurut Witjaksonoa dan Djaddang (2018, h.99) mengenai "Peran Corporate Social Responsibility (CSR) dunia bisnis dituntut untuk mampu menyeimbangkan pencapaian kinerja ekonomi (profit), kinerja sosial (people), dan kinerja lingkungan (planet) atau disebut triple bottom-line." Sehingga dapat dipahami untuk menyelesaikan masalah ini di butuhkan triple bottom line yang merupakan inti dari kewirausahaan berkelanjutan.

Menurut Cohen, dkk. (2007) kewirausahaan berkelanjutan dapat menyelesaikan permasalahan ekonomi, sosial, dan lingkungan. Kewirausahaan berkelanjutan mengacu pada penemuan, penciptaan, dan eksploitasi peluang kewirausahaan yang berkontribusi pada keberlanjutan dengan menghasilkan keuntungan sosial dan lingkungan untuk orang lain di masyarakat (Hockerts \& Wüstenhagen, 2010; Pacheco dkk., 2010; Shepherd \& Patzelt, 2011).

Berdasarkan penelitian sebelumnya, menurut Dissanayake (2013) menegaskan bahwa keyakinan perilaku, efikasi diri dan kredibilitas berpengaruh secara signifikan terhadap intensi kewirausahaan pada mahasiswa program studi yang dipilih. Dalam hal di atas keyakinan perilaku, efikasi diri, dan kredibilitas merupakan bagian dari perceived entrepreneurial feasibility dimana berpengaruh sevara singnifikan terhadap niat kewirausahaan pada mahasiswa. 
Selain itu, berdasarkan penelitian sebelumnya niat kewirausahaan yang berorientasi keberlanjutan didorong oleh sikap terhadap keberlanjutan dan persepsi keinginan kewirausahaan yang dirasakan. Kedua sikap ini didorong oleh altruisme dan penghargaan ekstrinsik, dimana penghargaan ekstrinsik memainkan peran yang berlawanan dalam kedua pendorong niat kewirausahaan yang berorientasi berkelanjutan (Vuorio dkk., 2007). Dalam penelitian tersebut diperoleh hasil attitude terbukti memiliki keterkaitan dengan niat kewirausahaan yang berorientasi berkelanjutan.

Penelitian ini bertujuan untuk menguji secara empiris mengenai pengaruh perceived entrepreneurial feasibility terhadap niat kewirausahaan yang berorientasi berkelanjutan dan untuk menguji secara empiris mengenai pengaruh attitude terhadap niat kewirausahaan yang berorientasi berkelanjutan. Penelitian ini diperluas dari yang sebelumnya hanya di Eropa, saat ini dilakukan pengujian di Indonesia.

\section{KAJIAN TEORI}

Perkembangan model niat dalam berwirausaha yang paling sering ditemukan adalah Theory of Planned Behavior dan Entreperenurial Event Theory. Literatur intensi berwirausaha telah memfokuskan pada lima tema utama : model intensi wirausaha inti, hubungan intensiwirausaha, faktor-faktor yang mempengaruhi intensi wirausaha (termasuk level individu, regional, budaya dan variabel kelembagaan), pendidikan kewirausahaan, dan kewirausahaan sosial dan berkelanjutan (Liñan \& Fayolle, 2015).

Saat ini telah muncul kewirausahaan baru yaitu kewirausahaan sosial dan berkelanjutan, yang banyak diberikan perhatian. Ada beberapa penelitian sebelumnya yang telah mengungkapkan adanya pengaruh dari beberapa faktor terhadap kewirausahaan ini, seperti menurut penelitian Vuorio dkk., (2007) niat kewirausahaan yang berorientasi berkelanjutan didorong oleh sikap terhadap keberlanjutan dan persepsi keinginan kewirausahaan yang dirasakan. Kedua sikap ini didorong oleh altruisme dan penghargaan ekstrinsik, dan, terutama, penghargaan ekstrinsik memainkan peran yang berlawanan dalam kedua pendorong niat kewirausahaan yang berorientasi keberlanjutan, selain itu hasil pengamatan pada mahasiswi kewirausahaan, ditemukan nilai hijau (keyakianan megaplikasiakan kepedulian lingkungan) yang dipersepsikan berpengaruh positif signifikan terhadap intensi berwirausaha berkelanjutan, sedangkan variabel lainnya tidak signifikan. Penelitian dari Kuckkertz dan Wagner ( 2010) menemukan hubungan positif antara orientasi keberlanjutan dan niat kewirausahaan di antara siswa sains dan teknik, tetapi tidak ada hubungan di antara siswa bisnis terhadap siswa sains dan teknik.

Penelitian mengenai niat kewirausahaan dalam konteks kewirausahaan berkelanjutan cenderung berfokus pada satu atau dua aspek penciptaan nilai (Cohen \& Winn, 2007; Dean \& McMullen, 2007; Hockerts \& Wustenhagen, 2010; Schaltegger \& Wagner, 2011 ; Shepherd \& Patzelt, 2011; Zahra dkk., 2009), dimana variabel Perceived Entreprenurial Feasibility dan Attitude ditambahkan dalam penelitian ini untuk memastikan apakah kedua variabel ini memiliki pengaruh terhadap niat kewirausahaan yang berorientasi berkelanjutan terhadap Mahasiwa/I Fakultas Ekonomi dan Bisnis Universitas Tarumanagara. 


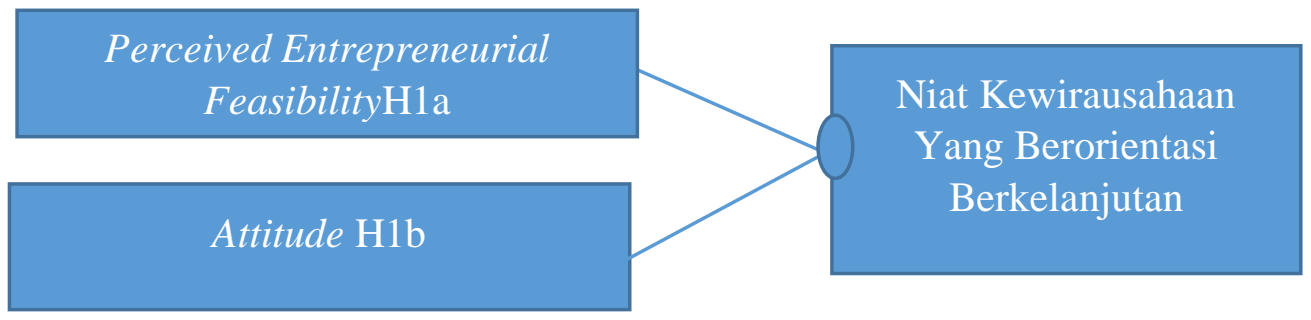

Gambar 1. Model Penelitian

Gambar di atas, untuk variabel independen yang pertama adalah Perceived Entrepreneurial Feasibility terdapat kaitan dengan niat kewirausahaan berkelanjutan, diketahui Perceived Entrepreneurial Feasibility mempertimbangkan keyakinan untuk menjalankan usaha dan juga mempertimbangkan sulit atau mudah untuk berwirausaha, dimana ketika seseorang memiliki kemampuan dan pengalaman maka dia akan sangat yakin dengan berwirausaha, dan sebaliknya, dalam niat kewirausahaan berkelanjutan ini dirasakan akan menimbulkan keyakinan seseorang karena ada pengaruh sosial dan lingkungan di dalamnya. Variabel kedua attitude merupakan perilaku psikologis mengenai hal positif atau negatif dari suatu objek, situasi, konsep, dan orang lain, yang memiliki kaitan secara sosial terhadap masyarakat. Attitude juga menggambarkan sejauh mana seseorang memiliki evaluasi yang menguntungkan atau tidak menguntungkan untuk menilai suatu perilaku yang berkaitan dengan niat kewirausahaan yang beroreientasi berkelanjutan. Perceived Entrepreneurial Feasibility dan Attitude mempengaruhi niat kewirausahaan yang berorientasi berkelanjutan. Sehingga dapat dirumuskan hipotesis sebagai berikut :

H1. Perceived Entrepreneurial Feasibility memiliki pengaruh yang signifikan pada niat kewirausahaan yang berorientasi berkelanjutan.

Perceived Entreprenurial Feasibility (kelayakan kewirausahaan yang dirasakan) berpengaruh positif dengan niat kewirausahaan di bidang kewirausahaan sosial (Mair \& Noboa, 2006; Smith \& Woodworth, 2012), penelitian ini mengungkapkan bahwa variabel perceived entreprenurial feasibility memiliki kaitan dengan kewirausahaan sosial, namun dirasakan juga berkaitan dengan kewirausahaan berkelanjutan. Tambahan dari penelitian Shapero dan Sokol (2005) dalam Krueger dkk. (2000) mengembangkan suatu model niat kewirausahaan yang disebut sebagai Shapero Entreperenurial Event Model. Model tersebut menjelaskan bahwa terjadinya niat kewirausahaan dipengaruhi oleh persepsi kelayakan (perceptions of fesibility) adalah persepsi tentang kemudahan atau kesulitan untuk memulai suatu usaha (Solesvik dkk.,2020). Penelitian diatas menyatakan bahwa kalau perceived entreprenurial feasibility memiliki kaitan dengan niat kewirausahaan, sehingga layak untuk dilakukan pengujian.

H2. Attitude memiliki pengaruh yang signifikan pada niat kewirausahaan yang berorientasi berkelanjutan.

Menurut Priyanto (2008) sikap merupakan salah satu faktor internal yang mempengaruhi pembentukan jiwa kewirausahaan selain faktor internal yang lain yaitu sifatsifat personal, kemauan dan kemampuan individu. Hasil serupa juga ditemukan oleh Ramaday (2014) bahwa sikap berpengaruh positif dan signifikan terhadap niat berwirausaha. Selain itu, banyak penelitian yang membuktikan bahwa sikap itu penting dan kuat, yang merupakan penentu niat kewirausahaan (Phan dkk.,2002; Moriano dkk.,2012). Selain memprediksi niat berwirausaha, sikap juga merupakan faktor yang kuat dalam mempengaruhi niat pro lingkungan dan keterlibatan keberlanjutan (Schick, Marxen \& Freimann, 2005; Tonglet, 
Philips \& Read, 2004). Penelitian di atas menyatakan bahwa attitude memiliki pengaruh yang signifikan terhadap niat kewirausahaan dan dirasakan juga berkaitan dengan niat kewirausahaan yang berorientasi berkelanjutan, sehingga layak dilakukan pengujian.

\section{METODOLOGI}

Penelitian ini dilakukan dengan menggunakan kuesioner dengan skala ordinal dimana subjek dalam penelitian ini adalah 170 Mahasiwa/I Fakultas Ekonomi dan Bisnis Universitas Tarumanagara, dimana generasi millenial atau generasi $\mathrm{Y}$ dipandang lebih sadar akan wirausaha, sadar sosial, dan sadar akan lingkungan dibanding generasi sebelumnya (Hewlett dkk., 2009). Dalam penelitian ini akan diuji pengaruh perceived entreprenurial feasibility dan attitude terhadap niat kewirausahaan yang berorientasi berkelanjutan. Dalam operasional variabel niat kewirausahan yang berorientasi berkelanjutan memiliki (Y) dengan 6 pernyataan, operasional variabel perceived entreprenurial feasibility (X1) memiliki 9 pernyataan, dan operasional variabel attitude (X2) memiliki 6 pernyataan.

Teknik pemilihan sampel dalam penelitian ini digunakan metode non probability sampling dengan teknik sampel purposive sampling. Menurut Notoatmodjo (2010), purposive sampling adalah pengambilan sampel yang berdasarkan atas pertimbangan tertentu seperti sifat-sifat populasi ataupun ciri-ciri yang sudah diketahui sebelumnya. Sedangkan kriteria penelitian ini adalah meliputi status responden yang merupakan mahasiswa, yang memiliki usia berkisar 17 sampai 22 tahun dan beberapa jenis kriteria lain seperti jenis kelamin, tempat tinggal, jurusan dan semester. Periode pengambilan sampel antara November-Desember 2020.

Dalam metode penelitian, analisis data merupakan suatu teknik yang penting untuk menghasilkan data yang diinginkan dan berguna untuk mencapai tujuan penelitian. Pada penelitian ini digunakan metode analisis data dengan menggunakan software SmartPLS versi 3.3.2 yang dirancang untuk mengestimasi persamaan structural. PLS atau Partial Least Square adalah analisis persamaan structural (SEM) berbasis varian yang dapat melakukan pengujian model pengukuran sekaligus pengujian model struktural.

Dalam penelitian ini, dengan menggunakan SmartPLS 3.3.2, model spesifikasi PLS dievaluasi dengan melakukan dua tahap yatu evaluasi outer model (model pengukuran termasuk validitas dan reliabilitas) serta inner model (disebut juga struktural). Partial Least Square memiliki beberapa keunggulan yaitu data tidak harus berdistribusi normal multivariat (indikator dengan skala kategori, ordinal, interval sampai rasio dapat digunakan pada model yang sama) dan ukuran sampel tidak harus besar. (Ghozali, 2008). Selanjutnya penelitian ini menggunakan Partial Least Square (PLS) dengan model penelitian yang terdiri dari uji validitas, uji reliabilitas, uji koefisien determinasi, uji path coefficients, goodness of fit dan pengujian hipotesis. Peneliti juga menggunakan bootstrapping atau resampling untuk dapat mengetahui nilai yang signifikan.

\section{HASIL ANALISIS DATA}

Pengujian validitas dan reliabilitas data pada penelitian ini menggunakan hasil dari pengujian outer model yang sudah dilakukan dimana nilai outer loadings pada setiap indikator memiliki nilai yang lebih besar dari 0,5 dan nilai Average Variance Extracted (AVE) diatas 0,5 sehingga nilai discriminant validity pada penelitian ini valid. Selanjutnya hasil uji reliabilitas pada penelitian ini menggunakan cronbach's alpha dan composite reliability yang memiliki nilai variabel diatas 0,6 dan diatas 0,7 , sehingga data pada penelitian ini sudah reliabel karena sudah memenuhi kedua kriteria tersebut. Data yang sudah valid dan reliabel ini kemudian diolah dengan menggunakan analisis koefisien determinasi $\mathrm{R}^{2}$ dengan hasil sebesar 0,619 atau $61,9 \%$, sehingga diketahui bahwa perceived entrepreneurial feasibility dan attitude 
memiliki pengaruh yang kuat terhadap niat kewirausahaan yang berorientasi berkelanjutan sebesar $61,9 \%$. Sedangkan 38,1\% niat kewirausahaan yang berorientasi berkelanjutan dipengaruhi oleh variabel lain yang tidak terdapat dalam penelitian ini. Selanjutnya Uji Qsquare dengan metode blindfolding memiliki nilai 0,376 menunjukan bahwa variabel perceived entrepreneurial feasibility dan attitude memiliki pengaruh yang kuat terhadap niat kewirausahaan yang berorientasi berkelanjutan, dan pengujian path coefficiens diperoleh persamaan dalam penelitian ini dengan $\mathrm{NKYBB}=0,259 \mathrm{PEF}+0,588 \mathrm{~A}$, dan dari persamaan NKYBB dimana PEF ditambah A mendapatkan hasil 0,847 yang menunjukan bahwa tingkat kelayakan model penelitian ini tergolong besar. Selanjutnya pengujian goodness of fit sebesar 0,592, maka dapat dikatakan bahwa kecocokan model yang digunakan pada penelitian ini tergolong besar. Berdasarkan persamaan tersebut dapat ditunjukkan bahwa hubungan variabel perceived entrepreneurial feasibility dan attitude terhadap niat kewirausahaan yang berorientasi berkelanjutan memiliki pengaruh yang positif.

Tabel 1. Hasil Path Coefficients

\begin{tabular}{|c|c|c|c|}
\hline & Original sampel & T Statistik & P Values \\
\hline $\begin{array}{c}\text { perceived entrepreneurial feasibility -> niat } \\
\text { kewirausahaan yang berorientasi } \\
\text { berkelanjutan }\end{array}$ & 0,259 & 3,000 & 0,003 \\
\hline $\begin{array}{c}\text { attitude -> niat kewirausahaan yang } \\
\text { berorientasi berkelanjutan }\end{array}$ & 0,588 & 7,930 & 0,000 \\
\hline
\end{tabular}

*Sumber: olahan data SmartPLS 3.3.2

Berdasarkan hasil path coefficients pada tabel 1.1 diatas, maka dapat diperoleh persamaan dalam penelitian ini yaitu $\mathrm{NKYBB}=0,259 \mathrm{PEF}+0,588 \mathrm{~A}$. berdasarkan persamaan tersebut dapat disimpulkan bahwa variabel independen (X1) yaitu perceived entrepreneurial feasibility memiliki pengaruh positif dan signifikan terhadap variabel dependen (Y) yaitu niat kewirausahaan yang berorientasi berkelanjutan dan variabel independen (X2) yaitu attitude memiliki pengaruh positif dan signifikan terhadap variabel dependen (Y) yaitu niat kewirausahaan yang berorientasi berkelanjutan.

Selanjutnya adalah pembahasan tentang uji hipotesis (path coefficient) dimana dalam penelitian ini menggunakan metode boothstrapping, berikut adalah hipotesispenelitian ini :

H1. Perceived Entrepreneurial Feasibility memiliki pengaruh yang signifikan pada niat kewirausahaan yang berorientasi berkelanjutan.

Hasil dari pengujian hipotesis yang pertama menunjukkan bahwa perceived entrepreneurial feasibility memiliki nilai t-statistik sebesar 2,924 yang berarti lebih besar dari 1,96 dan nilai pvalues perceived entrepreneurial feasibility sebesar 0,004 yang berarti lebih kecil dari 0,05 atau 5\%. Sehingga dapat disimpulkan bahwa perceived entrepreneurial feasibility memiliki pengaruh yang signifikan terhadap niat kewirausahaan yang berorientasi berkelanjutan mahasiswa Fakultas Ekonomi dan Bisnis Universitas Tarumanagara.

H2. Attitude memiliki pengaruh yang signifikan pada niat kewirausahaan yang berorientasi berkelanjutan.

Hasil dari pengujian hipotesis yang kedua menunjukan bahwa pengujian attitude terbukti berpengaruh secara signifikan terhadap niat kewirausahaan yang berorientasi berkelanjutan pada mahasiswa Fakultas Ekonomi dan Bisnis Universitas Tarumanagara, dikarenakan hasil dari nilai t-statistik attitude sebesar 7,791 yang berarti lebih besar dari 1,96 dan p-values attitude sebesar 0,000 yang berarti lebih kecil dari 0,05 atau 5\%. Sehingga dapat disimpulkan 
bahwa attitude memiliki pengaruh yang signifikan terhadap niat kewirausahaan yang berorientasi berkelanjutan.

\section{DISKUSI}

Berdasarkan tujuan penelitian ini adalah untuk menguji secara empiris mengenai pengaruh perceived entrepreneurial feasibility terhadap niat kewirausahaan yang berorientasi berkelanjutan dan untuk menguji secara empiris mengenai pengaruh attitude terhadap niat kewirausahaan yang berorientasi berkelanjutan. Berdasarkan temuan yang sudah diuji sebelumnya maka ditemukan bahwa :

Pertama, perceived entrepreneurial feasibility memilki pengaruh positif dan signifikan terhadap niat kewirausahaan yang berorientasi berkelanjutan, Hal tersebut sesuai dengan penelitian yang telah dilakukan oleh Dissanayake, D.M.N.S.W., (2013) dimana menegaskan bahwa keyakinan perilaku, efikasi diri dan kredibilitas yang merupakan bagian perceived entrepreneurial feasibility berpengaruh secara signifikan terhadap intensi kewirausahaan. Perceived entrepreneurial feasibility didapatkan dari proses atau pengalaman namun yang terbesar adalah dari kepercayaan diri, kemampuan dan pendidikan, ketika seseorang sudah sangat yakin dalam melakukan kewirausahaan yang berorientasi berkelanjutan maka seseorang tentu sudah memiliki keyakinan terhadap dirinya dan kemampuannya, seperti sudah siap ketika mengadapi berbagai permasalahan, atapun siap dalam mengalami kerugian. Keyakinan ini membuat seseorang memiliki kelayakan untuk membuka sebuah usaha/ bisnis yang berorientasi berkelanjutan yang memikirkan kepentingan lingkungan dan masyarakat. Tidak setiap orang memiliki keyakinan dan kelayakan ini namun hal ini bisa dikumpulkan dari setiap proses dan pengalaman, dan tentunya latar belakang kebaikan untuk membantu menyelesaikan masalah lingkungan dan sosial akan membuat seseorang memiliki keyakinan dalam melakukan kewirausahaan yang berorientasi berkelanjutan.

Kedua, attitude berpengaruh posited dan signifikan terhadap niat kewirausahaan yang berorientasi berkelanjutan, hal tersebut sesuai dengan penelitian yang telah dilakukan oleh Vuorio dkk (2007) yang menyatkan bahwa niat kewirausahaan yang berorientasi keberlanjutan didorong oleh sikap terhadap keberlanjutan. Selain itu, sejalan dengan penelitian Nuringsih, dkk. (2019) yaitu sikap nilai hijau (keyakianan megaplikasiakan kepedulian lingkungan) yang dipersepsikan berpengaruh positif signifikan terhadap intensi berwirausaha berkelanjutan. Dengan adanya hasil dari penelitian di atas maka sudah terbukti bahwa attitude berpengaruh signifikan dan berhubungan positif terhadap niat kewirausahaan yang berorientasi berkelanjutan. Sehingga sikap seseorang terhadap sebuah kejadian atau pristiwa menentukan apakah dia menganggap hal itu sebagai sebuah peluang positif atau tidak. Sikap setiap orang berbeda dalam kondisi yang berbeda namun keputusan yang di ambil tentu akan selalu mengikuti attitude atau niat hatinya, maka ketika seseorang yang dari kecil di didik untuk peduli lingkungan dan orang sekitarnya maka pada umumnya mereka akan cenderung untuk memiliki rasa peduli, terutama pada saat melihat kejadian/bencana mereka akan tergerak untuk melakukan sesuatu yang dapat membantu setiap permasalahan yang terjadi, sehingga mereka yang tergerak akan menciptakan sebuah bisnis yang bisa mengatasi permasalahan yang terjadi, tentu harus di latar belakangi sebuah pengalaman dalam dunia bisnis atau informasi bisnis.

\section{PENUTUP}

Berdasarkan data dari 170 responden Mahasiswa/I Fakultas Ekonomi dan Bisnis Universitas Tarumanagara, diperoleh kesimpulan sebagai berikut : perceived entrepreneurial feasibility berpengaruh positif dan signifikan terhadap niat kewirausahaan yang berorientasi berkelanjutan pada Mahasiswa/I Fakultas Ekonomi dan Bisnis Univeristas Tarumanagara. 
attitude berpengaruh positif dan signifikan terhadap niat kewirausahaan yang berorientasi berkelanjutan pada Mahasiswa/I Fakultas Ekonomi dan Bisnis Univeristas Tarumanagara.

Saran Terkait dengan hasil penelitian yang sudah dilakukan, berikut beberapa saran yang diharapakan dapat bermanfaat : Universitas Tarumanagara sebaiknya mempertimbangkan untuk memberikan pendidikan kewirausahaan berkelanjutan agar setiap mahasiswa lebih sadar akan manfaat dari adanya kewirausahaan berkelanjutan sehingga dapat diharapkan kelak Mahasiswa/I Universitas Tarumanagara dapat menjadi wirausaha yang bukan hanya memperhatikan aspek ekonomi namun juga memperhatikan aspek sosial dan lingkungan. Selain itu penerapan nilai kewirausahaan seperti keterampilan, pengetahuan, dan sikap dalam kewirausahaan perlu lebih sering di praktekan pada mahasiswa. Untuk peneliti selanjutnya disarankan untuk menambah variabel keinginan kewirausahaan dan variabel lainnya, terutama untuk melakukan penelitian dengan jangkauan yang lebih luas, agar mendapatkan hasil yang lebih optimal. Untuk peneliti selanjutnya, disarankan untuk jangkauan dalam pengambilan sampel dan daerah yang akan diteliti diperluas lagi untuk dapat memperkuat dan melengkapi penelitian sebelumnya, terutama di daerah-daerah diluar ibukota.

\section{DAFTAR PUSTAKA}

Amelinda, R., Prasodjo, I., Nuringsih, K., \& Nuryasman, M. N. (2019). Sustainable entrepreneurial intention: The perceived of triple bottom line among female students. Jurnal Manajemen, 23(2), 168. https://doi.org/10.24912/jm.v23i2.472

BPS. (2019, July 15). Badan Pusat Statistik. https://www.bps.go.id/pressrelease/2019/07/15/1629/persentase-pendudukmiskin-maret-2019-sebesar-9-41-persen.html

BPS. (2020, November 5). Data BPS: Jumlah Pengangguran Bertambah 2,67 Juta orang. merdeka.com. https://www.merdeka.com/uang/data-bps-jumlah-pengangguranbertambah-267-juta-orang.html

Cohen, B. and Winn, M.I. (2007), "Market imperfections, opportunity and sustainable entrepreneurship", Journal of Business Venturing, Vol. 22 No. 1, pp. 29-49

Dissanayake, D. (2014). The impact of perceived desirability and perceived feasibility on entrepreneurial intention among undergraduate students in Sri Lanka: An extended model. Kelaniya Journal of Management, 2(1), 39. https://doi.org/10.4038/kjm.v2i1.6543

Eagly, Chaiken, \& Sarlito. (1992). OPAC - Universitas Indonesia Library. https://lib.ui.ac.id/file?file=digital/125235-152.4\%20KHA\%20p\%20\%20Perbedaan\%20sikap\%20-\%20Literatur.pdf

Fellnhofer, K., Puumalainen, K., \& Vuorio, A. M. (2018). Drivers of entrepreneurial intentions in sustainable entrepreneurship. International Journal of Entrepreneurial Behavior \& Research, 24(2), 359-381. https://doi.org/10.1108/ijebr-03-2016-0097

Ghozali. (2018, August 25). Partial least Square. Uji Statistik. https://www.statistikian.com/2018/08/pengertian-partial-least-square-pls.html

Hidayati, N. (2013, March 20). https://core.ac.uk/download/pdf/234031768.pdf

Hockerts, Wüstenhagen, Pacheco, Shepherd, \& Patzelt. (2010). Neliti. https://media.neliti.com/media/publications/170968-ID-pemuda-indonesia-dankewirausahaan-sosia.pdf

Kuckertz, A., \& Wagner, M. (2010). The influence of sustainability orientation on entrepreneurial intentions - Investigating the role of business experience. Journal of Business Venturing, 25(5), 524-539. https://doi.org/10.1016/j.jbusvent.2009.09.001 
Krueger, C., Shapero, B., \& Sokol, A. (1993) Drivers of entrepreneurial intentions in sustainable entrepreneurship. International Journal of Entrepreneurial Behavior \& Research, 24(2), 359-381. https://doi.org/10.1108/ijebr-03-2016-0097

Liñan, \& Fayolle, (2015). Drivers of entrepreneurial intentions in sustainable entrepreneurship. International Journal of Entrepreneurial Behavior \& Research, 24(2), 359-381. https://doi.org/10.1108/ijebr-03-2016-0097

MARCO, L. (2019). Pengaruh orientasi pasar dan orientasi kewirausahaan terhadap kinerja umkm pada bidang variasi mobil di mega glodok kemayoran jakarta pusat. International Journal of Retail \& Distribution Management , 43, 280-596.

Muselman. (2009). Drivers of entrepreneurial intentions in sustainable entrepreneurship. International Journal of Entrepreneurial Behavior \& Research, 24(2), 359-381. https://doi.org/10.1108/ijebr-03-2016-0097

Mair, B., \& Noboa, G. (2006) Valuasi kesadaran lingkungan, corporate social responsibility terhadap kualitas laba dengan moderasi komite audit. jurnal ekonomi dan bisnis, 21, 97114. https://doi.org/10.17528/cifor/001641

Notoatmodjo. (2017, July 31). Penjelasan Teknik purposive sampling Secara detail. Uji Statistik. https://www.statistikian.com/2017/06/penjelasan-teknik-purposivesampling.html

Noboa, G., \& Mair, B. (2006) Valuasi kesadaran lingkungan, corporate social responsibility terhadap kualitas laba dengan moderasi komite audit. jurnal ekonomi dan bisnis, 21, 97114. https://doi.org/10.17528/cifor/001641

Prasodjo, I., Amelinda, R., Nuringsih, K., \& Nuryasman, M. N. (2019). Sustainable entrepreneurial intention: The perceived of triple bottom line among female students. Jurnal Manajemen, 23(2), 168. https://doi.org/10.24912/jm.v23i2.472

Puspayoga, A. G. (2020, October 20). Jumlah Pengusaha Di Indonesia Meningkat, TAPI... KoinWorks meningkat/

Priyanto, M. (2008). Neliti. https://media.neliti.com/media/publications/220474-analisisfaktor-faktor-yang-mempengaruhi.pdf

Phan, H., \& Moriano, H. G. (n.d.). Neliti. https://media.neliti.com/media/publications/254988pengaruh-sikap-pendidikan-dan-lingkungan-6c398169.pdf

Puumalainen, K., Vuorio, A. M., \& Fellnhofer, K. (2018). Drivers of entrepreneurial intentions in sustainable entrepreneurship. International Journal of Entrepreneurial Behavior \& Research, 24(2), 359-381. https://doi.org/10.1108/ijebr-03-2016-0097

Rosana, M. (2018). KEBIJAKAN PEMBANGUNAN BERKELANJUTAN YANG BERWAWASAN LINGKUNGAN DI INDONESIA. Jurnal ilmu sosial, 1. https://doi.org/10.17528/cifor/001641

Ramaday. (2014). Neliti. https://media.neliti.com/media/publications/254696-pengaruh-sikapmotivasi-dan-lingkungan-t-256236f5.pdf

Shapero, R., \& Sokol, D. (2006) Valuasi kesadaran lingkungan, corporate social responsibility terhadap kualitas laba dengan moderasi komite audit. jurnal ekonomi dan bisnis, 21, 97114. https://doi.org/10.17528/cifor/001641

Solesvik, G. (2020). Neliti. https://media.neliti.com/media/publications/221197-keterkaitanpengalaman-kewirausahaan-sik.pdf

Vuorio, A. M., Puumalainen, K., \& Fellnhofer, K. (2018). Drivers of entrepreneurial intentions in sustainable entrepreneurship. International Journal of Entrepreneurial Behavior \& Research, 24(2), 359-381. https://doi.org/10.1108/ijebr-03-2016-0097

Witjaksono, R. B., \& Djaddang, S. (2018). Valuasi kesadaran lingkungan, corporate social responsibility terhadap kualitas laba dengan moderasi komite audit. jurnal ekonomi dan bisnis, 21, 97-114. https://doi.org/10.17528/cifor/001641 
Winn, V., Cohen, C., Dean, G., McMullen, G., \& Hockerts, H. (n.d.). Simple search. https://www.diva-portal.org/smash/get/diva2:711153/FULLTEXT01.pdf 